\title{
Climate Change, Effects and Mitigation Strategies on Aquaculture: A Review
}

\author{
Anyanwu C. N., Amadi-Eke A. S., Nwaka D. E., Ezeafulukwe, C. F., Adaka, G. S. \\ Department of Fisheries and Aquaculture Technology, Federal University of Technology Owerri Imo State Nigeria
}

\section{Email address:}

anyanchris@yahoo.com (Anyanwu C.N.)

\section{To cite this article:}

Anyanwu C. N., Amadi-Eke A. S., Nwaka D. E. Ezeafulukwe, C.F., Adaka, G.S. Climate Change, Effects and Mitigation Strategies on Aquaculture: A Review. Agriculture, Forestry and Fisheries. Special Issue: Environment and Applied Science Management in a Changing Global Climate. Vol. 4, No. 3-1, 2015, pp. 70-72. doi: 10.11648/j.aff.s.2015040301.22

\begin{abstract}
This paper review and addresses the major effects of climate change on Aquaculture, whose contributions to agriculture development are quite enormous. To achieve these objectives the status of this sub sector to the total fish supply are therefore analyzed with a view to identifying the major impacts of climate change on aquaculture. Aquaculture not practiced evenly across the globe requires an evaluation of the effects of climate change through the current aquaculture practices in the regions and the different environments. The main elements of climate change that would impact on aquaculture production include sea level and temperature rise, change in monsoon patterns and extreme climatic events and water stress, among others thereby causing varying degrees of concern either positively or negatively or directly or indirectly. Therefore, to ameliorate this adverse effect of climate change on aquaculture in Nigeria, and the world generally, attempts are made to deal with the climate change effects on the different culture systems in order to bring out all the complex attributes of climate change and the possible mitigation strategies for the future control. These will enhance aquaculture production and then claim back the expected role as a major source of animal protein in the future.
\end{abstract}

Keywords: Aquaculture, Climate Change, Effects, Potential, Mitigation

\section{Introduction}

Over the last two to three decades, aquaculture has successfully established itself as a major food subsector, providing significant proportion of the animal protein needs across all communities irrespective of their moving standards. As with other food produce sectors aquaculture now confronts major challenge, that of the climate change. Human food needs and food production are impacted by climate variations and such changes in the coming decades are a major concern particularly in developing nations. The threats of climate change to human society and natural resources have been given top priority since the release of the fourth assessment report of the inter governmental panel on climate change [1]. Over the past ten years now, climate variations and the general consequences have been so loosely and indiscriminately used and interpreted in many quarters forth many scientific data and analyses. The most important changes that are associated with climate change include gradual rise in global temperature, and that of the green house gases [2] leading to flooding and water stress consequences. Though the contributions of aquaculture to climate change through green house gas emissions are quit enormous, the implications of climate change on aquaculture cannot be ignored. Aquaculture accounts for close to $(50 \%)$ fifty percent of the present global fish consumption [4], and having played significant roles in food supply. Food security and also generate income to fish farmers. Aquatic foods have high nutritional value, contributing twenty $(20 \%)$ percent or more protein intake of more than 1.5 billion people, mostly in the developing countries. Fish contains n-3 (DHA, EPA) and n-6 (AA) unsaturated fatty acids. It is also rich in lysine and methionine amino acids, vitamins and minerals (iodine and selenium). The constitution of fish with highly unsaturated fatty acids of n-3 and n-6 series has been the major antidote for people with high cholesterol lands. Recently, it is noted that some of the deficiencies of some of the poly unsaturated fatty acids (PUFAS) are associated with major health risks [5] and some diseases, most of which are alleviated by supplementing with these polyunsaturated fatty acids. Based on the above facts this paper therefore focused on the potential importance of aquaculture to poverty reduction (mankind) and also captures the effects of climate change on 
aquaculture and proposes how mitigation strategies could be maintained and enhanced in the face of world global health consequences.

\section{Effects of Climate Change on Aquaculture}

Effects of climatic change on aquaculture could be either positive or negative and emanates from the direct and indirect impacts on natural resources that are necessary for aquaculture production. These resources include water, land, seed, feed and energy inputs.

\subsection{Directs Effects}

The first direct effect of climate change in aquaculture dates back to the smog cloud of 2002 from the Southeast Asia. The effect reduced sunlight and heat to the lower atmosphere and the oceans by ten percent, resulting to large dinoflagellate blooms in the coastal areas and severe damages to aquaculture and economics losses that worth millions of Dollars.

\subsection{Potential Direct Effects}

Some of the potential direct effects of climate change on aquaculture include:

\subsubsection{Global Warming and Temperature Increase with Associated Effects}

The effects on pond aquaculture through solar radiation, air temperature, wind velocity and water turbidity results to increase in vaporization, cloud cover and subsequent reduction in solar radiation reaching the ponds and hence the occurrence of algal blooms and red tides on the surfaces of water which can affect the water quality and survival of fish in the ponds. It also has effect on agriculture where an increase in global acidification can affect calcareous shell formation in mollusks. On integrated aquaculture the persistent $\mathrm{H}_{5}$ and $\mathrm{H}_{7}$ avian influenza a virus strains are feared. But the established inverse relationship to temperature and salinity of water reduces fear of risks to human health [6].

\subsubsection{Saline Water Intrusion}

Global warming, which is the persistent increase in global temperature due to the emission of green house gases, causes rise in sea levels as the icebergs melt due to high temperature resulting to the rise in temperature volume beyond the river banks [7] and increase in salinity intrusion upstream that affects the freshwater culture practices.

\subsubsection{Water Stress}

Climate change causes decreased water availability in major rivers and streams in most developing countries of Asia and Africa [8] causing major effects in fish spatoning, migration and seed availability for cage famers. It can also lead to increase drought periods that results to less water retention time in non-perennial water bodies [9].

\subsubsection{Changes in Monsoon Patterns and the Occurrence of Extreme Weather Events}

Climate variations effects also comes through, typhoons, hurricanes and unusual floods that increases heavily, resulting to huge economic losses, large storms e.g. in Southern Chile damaging Salmon industry and resulting to large escapes from sea cages [10]. It also causes severe weather changes both in water quality and pollution and in other damaging run-oft due to flooding, and loss of livelihoods among aqua cultural farmers.

\section{Indirect Effects}

The most common discussed indirect effects of climate changes on aquaculture are:

Fish meal and fish oil supplies: Loss of productivity from the capture fisher oils can cause fewer raw materials availability for fish meal and fish oil industry. The changes in the ocean circulation patterns can influence fish meal and fish oil supplies [11].

Soybean meals and corn meal supplies: The use of soyabean meals and corn meal for the production of biofuel instead of the usual feed formulation poses both economic and social challenges especially in the aquaculture subsector.

\subsection{Effects on Diseases}

The increase in incidence of disease outbreaks in the coastal and marine animals together with other new diseases has been reported [12]. Increased water temperature stress fish and facilitate diseases [13] while increased uptake of toxicants and heavy metals results to increased temperature of cultured mollusks thereby making them vulnerable to disease outbreak.

\subsection{Effects on Biodiversity}

Climate changes affect exotic species competing with indigenous species for both food and space. [14] due to increase in storm surges and tropical clones leading to incidence of aquaculture stocks escaping into the wild environment. This also alters their habitats [15] transmits pathogenic organisms as well as genetic interactions through hybridization and introgression [16].

\section{Some of the Mitigation Strategies to Cushion the Effect of Climate Change Include the Following}

1. The need to reduce pressure on both the social and economic developments by slowing down population growth of developing nations.

2. By adopting forest conservation measures which will include the prohibition of forestland for non forest purposes, encouraging afforestation and reafforestation activities.

3. Including climatic studies in our school curriculum to 
create awareness and educate the citizens at both, the local, state and national levels.

4. Integrate climate issues into economic planning and management by promoting policies and programmes of climate change into the local, state and national levels.

\section{Conclusion}

Climate change as established is a serious threat to both natural resources and humanity generally. Unlike the other animal meat, production sectors, aquaculture is less distributed with concentrations mostly in the tropical and subtropical regions of Asia and Africa and to lesser extent on the temperate regions of Europe and South America. Given the distribution, it is expected that the major climate change effects on aquaculture would be through the global warming and the consequent temperature increases in water. Sea level rise and associated water intrusion, coupled with monsoon weather pattern changes in the tropical and subtropical regions where the major aquaculture activities take place will impact more in the deltaic areas of the tropics. More so, the potential increased pressure on fresh and marine water availability and quality and the expected climatic changes, with its enormous influence on static water bodies through eutrophication and stratification can result to heavy mortality of the cultured stock, through up welling, oxygen depletion and nutrient loss.

\section{References}

[1] IPCC, 2007. The physical science basis: Working group I contribution to the fourth Assessment Report on the IPCC, Cambridge University press Cambridge, M.A, U.S.A. ISBN 13:978 0521880091, pages 996.

[2] Brook, F.J, Sowers, T and Orchado, J (1996). Rapid varia5tion in atmospheric methane concentration during past 110,000 years. Science, 273:1087-1990.

[3] FAO (2008B). FAO Food outlook, 2008, Rome, FAO.

[4] De Deckere, E.A.M, Korver, O, Verschuren, P.M. and Katan, M.B. (1998). Health as pects of fish and n-3 polyunsaturated acids from plant and marine origin Europen Journal of Clinical Chemistry 52:7749-753.
[5] Brown, I.D, Swayne, D.E, Cooper, R.J, Burns, R.F. and Stallknecht, D.E. (2006): Persistence of $h_{5}$ and $h_{7}$ avian influenza virus in water, Avian disease, 50:236-242.

[6] Onumadu F. N. (2010) Agro forestry Extension. As an Effective Tool for Mitigating Climate Change in Nigeria.In: S .K Adeyoju and S. O. Bada (eds)

[7] Readings in Sustainable Tropical Forest Management: Essays in Honour of Professor Labode Popoola .Zenith book House 3, Lydia Close, Ashi, Bodija Pp 53-75

[8] IPCC, In Climate Change: The IPCC Scientific Assessment (eds Houghton, J. T., Jenkins, G. J. And Ephraums, J. J.), Cambridge University Press, Cambridge, UK, 1990.

[9] Goswani, B.N, Venugopal, V Sengupta, D Madhusoodanan, M.S and Xavier, P.K. (2006). Increasing trend of extreme rain events in a warming environment. Science 314: 14442-1445

[10] Soto, D, Jara, F and Moreno, C. (2001) Escaped Salmon in the miner seas, Souther Chile facing ecological and social conflicts 1. Ecological applications 11 (6):1750-1762.

[11] Pile, I.H. and Barlow, S.M. (2002). Impacts of fish farming on fish, Bordeaux. Aquaculture and environment symposium, Boroleaux, France.

[12] Harvell, C.D, Kin, K, Burkholder, J.M, Colwell, R.R, Epstein, P.R, Grimes, J. Hofinann, R, Porter, J.W, Smith, G, WandVasta, G.R. (1999). Emerging marine disease-Climate links and anthropogenic factor. Science, 285: 1505-1510.

[13] Snieszko, S.F. (1974). The effects of environmental stress on outbreaks of infectious diseases of fish. Journal of fish biology, 6(2):197-208.

[14] Fike, A.D. (Myrick, C.A. and Hansen, L.T. 2007). Potential impacts of global climate change on fresh water fisheries. Reviews in fish biology and fisheries, 17:581-613.

[15] Collares-Pereira, M.J and Cowx, I.G (2006). The role of catchments scale environmental management in fresh water fish conservation. Fisheries management and Ecology, $11: 303-312$.

[16] Araguas, R.M, Sanz, N, Pla, C and Garcia Martin J.1. (2004). Breakdown of the brown trout evolutionary history due to hybridization between native and, Cultivated Fish. Journal of fishbiology, 65 (supplement A):28-37. 